\title{
Legal implications of the step-by-step principle
}

\author{
Caroline von Kries ${ }^{1^{*}}$ and Gerd Winter ${ }^{2^{*}}$
}

\begin{abstract}
Purpose: The 'step-by step' principle was introduced into the European Union legislation on genetically modified organisms as a means to cope with uncertainty about environmental risks from the release of genetically modified organisms into the environment. The approval process is orientated along the stepwise reduction of containment which reflects a precautionary approach towards the risks of genetically modified organism release. Thus, the gradual reduction of containment should keep pace with the gradual generation of risk-related knowledge. This paper strives to clarify the meaning, legal status and practical importance of the principle. It also looks at whether non-European Union countries have adopted the principle as well, and how they practice it.

Methods: The article is based on research of the relevant legal texts, court cases and legal literature. In addition, a number of dossiers of applications for the European Union authorisation of release and placing on the market of genetically modified seed were analysed.

Results and conclusions: Although 'step-by-step' is not a precise legal rule it does have legal meaning as a principle guiding the risk assessment and management of genetically modified organism introduction into the environment. Assuming a process of gradual reduction of containment and scaling up of release ranging from closed systems via experimental release to cultivation the 'step-by-step principle' requires that the knowledge on environmental risks of genetically modified organisms should be generated on stages previous to the ones where the risk can result in damage. The analysis of the legislation of China, the United States of America and Brazil showed a differentiated approach towards the step-by-step principle.
\end{abstract}

Keywords: step-by-step principle, release, placing on the market, monitoring, EFSA

\section{Analysis}

\section{'Step-by-step' in the relevant legal texts}

The 'step-by-step' principle was introduced by Directive 2001/18/EC [1] where it appears as numbers (24) and (25) of the preamble:

'(24) The introduction of GMOs into the environment should be carried out according to the "step by step" principle. This means that the containment of GMOs is reduced and the scale of release increased gradually, step by step, but only if evaluation of the earlier steps in terms of protection of human health and the environment indicates that the next step can be taken.

\footnotetext{
* Correspondence: caroline.v.kries@gmx.de; gwinter@uni-bremen.de 1 Im Hoeflin 22, Freiburg im Breisgau, D 79117, Germany 2University of Bremen, Department of Law, Institute for European Environmental Law (FEU), Bremen, D 28334, Germany Full list of author information is available at the end of the article
}

(25) No GMOs, as or in products, intended for deliberate release are to be considered for placing on the market without first having been subjected to satisfactory field testing at the research and development stage in ecosystems which could be affected by their use.'

Directives must be transposed into Member State law allowing them some legislatory discretion. In German law, for example, 'step-by-step' is framed in a rather broad language requiring that the risk assessment shall be based on experiences made on previous steps (GenTVfV 1996 Sec. 5 (2), 6 (2) [2]). Contrastingly, the Austrian Gentechnikgesetz [2] establishes 'step-by-step' as a binding precondition of authorisations. See Section 3 (3) which reads:

'The release of GMOs may only be performed step by step meaning that the containment of the GMOs may stepwise be unclenched and the scale of release

\section{空 Springer}


only be increased if the assessment of the earlier step indicates that the next step is compatible with the precautionary principle.'

A similar rule is contained in Art. 6 (2) of the Swiss Gentechnikgesetz ([2,3]: 170).

\section{Scope of application of the step-by-step principle}

The principle is applicable to all authorisation procedures concerning the experimental release and the placing on the market of genetically modified organisms (GMOs) which results in the subsequent introduction of GMOs into the environment.

While Regulation (EC) 1829/2003 [4] establishes a special authorization regime for food and feed, including also GMOs for cultivation of food and feed, Art. 6 (4) and Art. 18 (4) of the same regulation refer to the environmental safety requirements of Directive 2001/18/EC [1]which also include the step-by-step principle.

\section{The use of the term 'step-by-step' in the GMO regime}

Besides the levels of containment, the phases of risk assessment (hazard identification, evaluation of adverse effects, evaluation of likelihood of adverse effects, estimation of risk, etc.) are also called steps. ${ }^{a}$ It would be less confusing if for the 'steps' of risk assessment the term 'tiers' was used instead. The levels of risk assessment (DNA, genome, organism, population, ecosystem) are sometimes also called steps. It is suggested to call them organismic and ecological levels.

\section{The difference between the step-by-step and the case-by- case principles}

'Case-by-case' (see Art. 4 (3) Directive 2001/18/EC [1]) means that risk information about one GMO and its release cannot without proper scrutiny be transferred to other GMOs. It allows, however, facilitating procedures if sufficient information has been obtained on certain GMOs and if the release of the GMO or the type of the GMO shall be repeated or performed at different sites (see Art. 7 Directive 2001/18/EC [1]). By contrast, 'stepby-step' can be understood as an auxiliary tool within the case-by-case approach. It is a tool helping to structure the information generation for certain GMOs.

\section{The legal status of the step-by-step principle}

Reflecting that the principle is part of considerations but not of the working text of Directive 2001/18/EC [1] it is (in its quality as European Union (EU) law) not a selfstanding requirement of authorisations [5]. It nevertheless has a legal value. First, it is a general principle explaining the overall philosophy for the introduction of GMOs into the environment, i.e. the stepwise reduction of containment going along with the accumulation of knowledge. Second, it is an interpretation guidance for the working provisions of the directive thus helping to specify the scope of documents to be submitted and the understanding of the material yardsticks of risk assessment.

\section{Basic information requirements for approval}

'Step-by-step' does not mean that the release of GMOs can simply be based on the state of the knowledge that is at the disposal of the competent authority. Rather, the applicant for approval bears the burden of submitting evidence that no adverse effect will be caused by the release. This implies that the applicant must if needed conduct certain tests, be it by his own initiative or upon request by the authority.

There are four requirements which the applicant must fulfil in that respect, and which if unfulfilled allows the authority to reject the application. These can be regarded as minimum postulates of the step-by-step principle:

- Submission of data on the parent organism, the recipient organism, the GMO and the effects of the GMO on human health, plant and animal health and the environment as listed in Art. 5 (3) and Annex III B Directive 2001/18/EC [1].

- Submission of an environmental risk analysis (ERA) as expounded by Annex II Directive 2001/18/EC [6]. A proper analysis of this kind will need to present results of basic tests which allow the authority to determine what kind of risks may be caused. The scope of this sort of tests seems however not to be clear yet. Some standardization has been achieved by [6] and [7].

- Execution and submission of additional tests on demand of the authority if there is grounded hypothesis for an adverse effect on health or the environment by the submitted ERA. This power can be derived from the requirement of Art. 4 Directive 2001/18/EC [1] that no adverse effect shall be caused.

- Submission of uncertainty analyses on all test results concerning health and environmental risks. ${ }^{\mathrm{b}}$

\section{Step-by-step in practice}

There are different situations during the application phase when reference to the step-by-step principle may be of importance.

\section{State of science and technology}

It is not allowed for the operator to argue that he/she cannot carry out a safety measure because the relevant science or technology is not yet developed. The step-bystep principle shall ensure that the state of science and technology is developed throughout the previous steps such that an adequate risk assessment can be made. If further previous scientific investigation is necessary at the stage of the administrative decision, the 
authorisation of experimental release or placing on the market must be denied.

\section{Residual risk}

The analysis of authorisation procedures shows that risk assessors and competent authorities frequently argue that additional studies are not needed because the assumed risk is 'negligible' or 'tolerable'. There are different reasons why society might decide to acquiesce with residual risk: The limits of scientific understanding which advises to apply 'praktische Vernunft' (practical reason) [8], and, alternatively or in addition, considerations of benefits drawn from new technologies. The authors suggest that a residual risk should only be accepted if it is balanced by a benefit. Such benefit is scientific progress at the stage of small or large-scale release and more environmentally friendly agriculture at the stage of placing on the market [9].

\section{Reference to other studies}

The operator can ask to be freed from certain tests if the relevant knowledge is available from other studies, under the condition that the other studies are valid and reliable. In particular, given possible effects from the positioning of donor traits in the recipient genome the other study must have been made on the same GMO. ${ }^{c}$ Likewise, testing conditions and methods must be similar. Our analysis of application dossiers shows however that the conditions of validity and reliability are often not respected (StepKo 2011, Draft final report June 2011. on file with authors, ch. 2).

\section{Blanket reference}

The operator can ask to be freed from certain tests referring to the fact that on previous steps no adverse effects have been noticed, but only under the condition that the waiver relates to a risk hypothesis which was tested within the previous step. The blanket formula that no adverse effect was noticed on previous steps is not an acceptable proof, because it is not guaranteed that appropriate tests have been performed, for there is no requirement on any step to actively generate knowledge for the next step. Neither the case specific monitoring nor the general surveillance obligations require such active attitude (see below).

\section{Submission of data from earlier steps}

The authority is entitled to ask the operator to submit all risk information obtained from earlier steps. Annex III B No D 13 Dir 2001/18 says that required for a notification of release is 'information about previous releases of the genetically modified plant, if applicable'. Even more explicit is Art. 13 (2) Dir 2001/18: 'The notification shall contain: (a) the information required in Annexes III and IV. This information shall [...] include information on data and results obtained from research and developmental releases concerning the impact of the release on human health and the environment' [1].
It should be noted that the obligation to submit the information from tests within earlier steps extends both to positive and negative results. As also unpredicted effects must be explored the submission of data is not bound to risk hypotheses.

\section{Authority's use of own knowledge}

Although the risk assessment must be prepared by the operator, the competent authorities must generate and use their own administrative knowledge in order to elaborate their own views. This follows from the so-called investigation principle that characterizes administrative procedures. In any case, the notifier must be given opportunity to comment on the information before the decision is taken.

\section{Use of information of other notifiers}

The authority is entitled to use risk information it has obtained from other applications if the other applicant gives his/her consent, Art. 6 (3), 13 (4) Directive 2001/18/EC [1] and Art. 31 Regulation (EC) 1829/2003 [4]. If the consent is refused the applicant must produce the data anew.

\section{Monitoring as an additional step within step-by-step}

Within certain limits the monitoring can be seen as an additional step of the step-by-step approach. The objective of monitoring is to identify effects of the $\mathrm{GMO}(\mathrm{s})$ on human health or the environment which have not been discovered at the stage of the environmental risk assessment. For deliberate releases this is generally expressed in Art. 6 (2) (v) Directive 2001/18/EC [1]. For the placing on the market, monitoring is differentiated into case-specific monitoring (i.e. the confirmation of any assumption regarding the effect of the GMO) and general surveillance (i.e. the identification of adverse effects which were not anticipated). The possibility of requiring monitoring does however not allow the competent authority to shift the testing of grounded risk hypotheses to the monitoring stage. As said earlier, it must deny authorisation if the test could have been performed within previous steps.

\section{No obligation for proactive testing}

Apart from the powers to order the control of the current test and to monitor effects, neither EU law nor national law endows authorities with powers to ask for tests whose sole purpose is to generate information relevant for the subsequent step. However, this does not hinder authorities to require, on the subsequent step, risk information which should have been generated on previous steps. It may be advisable that competent authorities develop non-binding guidance which advises what tests should be performed on what steps. ${ }^{\mathrm{d}}$

\section{Comparative law: the step-by-step principle in non-EU countries}

We have selected for further study the USA, Brazil and China because they have a long-standing practice of authorising the release of GMOs. 
In the USA, there is no comprehensive law on genetic engineering. Rather, gene technology is spread over the already existing laws controlling risks from releases of products. For instance, genetically modified seeds are regulated either by the Plant Protection Act, the Federal Insecticide, Fungicide and Rodenticide Act or the Toxic Substances Control Act depending on whether they may cause adverse effects on plants, have insecticide properties or may have other toxic effects [10]. The National Environmental Pollution Act (NEPA) requires to prepare an environmental impact statement if a preliminary test indicates that a modified plant will be 'significantly affecting the quality of the human environment. 'e The step-by-step principle, however, is not mentioned, at least not on the level of laws. Rather, it appears as part of a guidance paper. ${ }^{f}$

'Development of organisms for agricultural or environmental applications should be conducted in a stepwise fashion, moving, where appropriate, from the laboratory to the growth chamber and greenhouse, to limited field testing and finally, to largescale field testing.'

This means that step-by-step is a general principle guiding research and development, but no specific requirement concerning individual authorisation procedures. It is true, however, that insofar as an EIA is required previous tests are necessary and thus some kind of step-by-step does materialize.

In Brazil, there is a general law regulating gene technology - the Law No. 11.105 of 24 March 2005 ([11]: 1073-1076). However, this law does not establish a stepby-step principle. The competent authority - the National Biosafety Technical Commission (CTNBio) although being by the law endowed with powers to establish principles of risk assessment on the sublegal level has not laid down a step-by-step principle, neither in a general nor in a specific sense. ${ }^{\mathrm{g}}$

In China, there is a special and comprehensive regulation on the safety of agricultural GMOs adopted in 2001 (Haigen $\mathrm{Xu}$ (2009) Unpublished analysis of Chinese law on genetically modified organisms, contribution to the StepKo-project). It contains rather specific provisions on the stepwise development and testing of agricultural GMOs. The relevant provisions of the Regulation read:

Article 13. The testing of agricultural GMOs shall generally go through three stages, i.e. restricted fieldtesting, enlarged field-testing and productive testing. The 'restricted field-testing' means a small-scale test conducted within a contained system or under controlled conditions.
The 'enlarged field-testing' means a medium-scale test conducted under natural conditions with appropriate safety control measures.

The productive testing means a large-scale test prior to commercial production and application.

Article 14. When an agricultural GMO needs to move on to the stage of restricted field-testing after the completion of research in laboratory, the organization conducting the test shall report to the competent agricultural administrative department of the State Council.

Further articles provide that reports on the results of earlier stages must be submitted when consent is searched for the next step. However, the material yardstick for authorisation is framed in rather vague terms. See Art. 1 which reads:

'These Regulations are formulated for the purposes of strengthening safety administration of agricultural genetically modified organisms (hereafter referred to as agricultural GMOs), safeguarding human health and safety of animals, plants and microorganisms, protecting the environment, and promoting research on agricultural GMOs.'

The overview of the three legislations shows that they starkly vary concerning the step-by-step principle. Brazil does not have it at all, the US has it as a general principle of policy, and China has it as a specific rule for the testing of GMOs. While it could be expected that it induces a particular cautious practice in China, the substantive yardsticks guiding the stepwise testing are not as strict and precautionary as those required by EU legislation. In conclusion, the step-by-step principle seems to have failed to move the three pro-GMO states into a direction which is as precautionary as the EU practice, although for different reasons: because it was not prescribed at all (Brazil), because it was not laid out as a specific requirement of authorisations (USA), or because it was not guided by precautionary substantive standards (China).

\section{Endnotes}

${ }^{a}$ See Annex II to Directive 2001/18/EC, ch. C [6].

${ }^{\mathrm{b}}$ This is general requirement of any sound science but it is also mentioned in [6] ch. 3 and [7] ch. 2.3.3.8.

${ }^{\mathrm{c}}$ This may be different concerning the study of effects of the parental lines.

${ }^{\mathrm{d}}$ See for a suggestion in that direction (StepKo 2011, Draft final report June 2011, on file with authors, ch. 4).

${ }^{\mathrm{e}} 42$ U.S.C. Section 4332(2)(C). The courts interprete this to mean that the agency must take a 'hard look' whether these conditions are given. See the landmark 
decision of the US District Court [12] for the Northern District of Califormia of 13 February 2007 (Geertson Seed Farms, 570 F. 3d 1130). The court quashed the decision of the competent authority to deregulate an herbicide-resistant alfalfa. The Supreme Court reversed the judgement but not in relation to the quashing of the agency's decision. Monsanto vs Geertson Seed Farms, No. 09-475, Decision of 21 June, 2010.

${ }^{\mathrm{f}}$ Recommendations Specific for Environmental and Agricultural Applications, Executive Office of the President, Office of Science and Technology Policy, Coordinated Framework for Regulation of Biotechnology, 51 FR 23302 June 26, 1986. http://usbiotechreg.nbii.gov/ CoordinatedFrameworkForRegulationOfBiotechnology1986.pdf

${ }^{g}$ The relevant law and sublegal acts are available in English at http://www.ctnbio.gov.br/index.php/content/ view/12840.html

\begin{abstract}
Acknowledgements
This article is an outcome of an interdisciplinary research project on the step-by-step procedure in gene technology (StepKo) sponsored by the German Bundesamt für Naturschutz (BfN). The authors wish to express their gratitude for many helpful comments by our collaborators Broder Breckling and Angelika Hilbeck as well as Andreas Heym, Thomas Meise, Beatrix Tappeser and Birgit Winkel from the BfN. Thanks are also due to Christoph Palme for valuable suggestions. Of course the views expressed by the authors do not necessarily reflect those of the BfN.
\end{abstract}

\section{Author details}

${ }^{1}$ Im Hoeflin 22, Freiburg im Breisgau, D 79117, Germany ${ }^{2}$ University of Bremen, Department of Law, Institute for European Environmental Law (FEU), Bremen, D 28334, Germany

\section{Authors' contributions}

Both authors have equally participated in the collection of material and elaboration of the text of the article.

\section{Competing interests}

The authors declare that they have no competing interests.

Received: 9 March 2011 Accepted: 21 September 2011

Published: 21 September 2011

\section{References}

1. Directive 2001/18/EC of the European Parliament and of the Council of 12 March 2001 on the deliberate release into the environment of genetically modified organisms and repealing Council Directive 90/220/EEC 2001, 1-39, OJ $L 106$.

2. GentVfV: Regulation on autorization and notification procedures according the Genetic Engineering Act - Gentechnikverfahrensverordnung of 1996, as amended 20081996.

3. Errass C: Öffentliches Recht der Gentechnologie im Außerhumanbereich Bern: Stämpfli; 2006.

4. Regulation (EC) No 1829/2003 of the European Parliament and of the Council of 22 September 2003 on genetically modified food and feed 2003, 1-23, OJ L 268.

5. Berlin VG: Administrative Court Berlin, judgement of 18 July 1995. Gentechnikrecht/Biomedizinrecht, Entscheidungssammlung 1995, Eberbach/ Lange/Ronellenfitsch (eds.) Nr. 7 zu § 16 GenTG.

6. Commission Guidance: Guidance notes on the objective, elements, general principles and methodology of the environmental risk assessment referred to in Annex II to Directive 2001/18/EC, Appendix to Annex II of Directive 2001/18/EC 2001.
7. EFSA Guidance: Guidance on the environmental risk assessment of genetically modified plants, EFSA panel on genetically modified organisms. EFSA Journal 2010, 8(11):1879.

8. BVerfG: Federal Constitutional Court, Judgement of 8 August 1978 (Kalkar). BVerfGE 1978, 49(143):89-147.

9. Winter G: Nature protection and the introduction into the environment of genetically modified organisms: risk analysis in EC multilevel governance. RECIEL 2008, 17(2):205-220.

10. Grossman MR: Genetically modified crops and food in the United States: the federal regulatory framework, state measures, and liability in tort. In The regulation of genetically modified organisms: comparative approaches. Edited by: Bodiguel L, Caedwell M. Oxford: Oxford University Press; 2010:

11. Leme Machado PA: Direito Ambiental Brasileiro. 18 edition. Sao Paulo: Malheiros Editores; 2010

12. US District Court: US District Court for the Northern District of California, Judgment of 13 February 2007 (Geertson Seed Farms) 2007, 570 F. 3d 1130.

doi:10.1186/2190-4715-23-32

Cite this article as: von Kries and Winter: Legal implications of the stepby-step principle. Environmental Sciences Europe 2011 23:32.

\section{Submit your manuscript to a SpringerOpen ${ }^{\mathcal{O}}$ journal and benefit from:}

- Convenient online submission

- Rigorous peer review

- Immediate publication on acceptance

- Open access: articles freely available online

- High visibility within the field

- Retaining the copyright to your article

Submit your next manuscript at $>$ springeropen.com 